\section{SMART ID CARD IN THAILAND FROM A BUDDHIST PERSPECTIVE}

\author{
Krisana Kitiyadisai $^{1}$
}

\begin{abstract}
The threat of terrorism and religious conflict has been intensifying around the world since the attack on the World Trade Center in the USA. Thailand has seen tense situations in the three Southern provinces in which the break down of intelligence gathering systems has been blamed for the failure in preventing attacks and ambushes by local separatists. Consequently, the Thai government implemented the smart ID card policy in order to improve public services, enable electronic transactions and facilitate counter terrorism efforts. The report by the British House of Commons' Home Affairs Select Committee has expressed concerns over the ID card scheme in the UK and a great deal of debate and discussion have centered on the impacts on human rights, privacy and liberty. However, this paper looks at the smart card scheme in Thailand from a Buddhist perspective, whether there is any Buddhist justification for supporting such a policy. Relevant Buddhist concepts will be the framework for investigating whether the smart card scheme, its objectives, and implementation process are objectionable or acceptable from a Buddhist perspective.
\end{abstract}

The tragic attack on the World Trade Center in the United States on 11 September 2001 has continued to exert far-reaching

\footnotetext{
${ }^{1}$ Department of Public Administration, Faculty of Political Science, Chulalongkorn University, Thailand
}

consequences and to cause repercussions on freedom and democracy as the war on terrorism rages on against the perceived threat. (Bunyan 2002) After the 9/11 event, several countries, such as the US, UK, the Netherlands, France, Italy, Greece and some Eastern European countries began to consider adopting national ID cards. (http://www.privacy.org/pi/activities/idcard) Some Asian countries such as the Philippines, Japan, Malaysia and Thailand, have also attempted to adopt a smart ID card policy. The unrest in the south of Thailand and the increase threat of terrorism have combined to push Thailand along the smart ID card scheme as a measure to counter terrorism. The Malaysian National Registration Department has indicated that many governments would be looking at identification systems to monitor people's movements as a result of the terrorist attack in the US (The Canberra Times, 21 September 2001). Consequently, the Thai and Malaysian governments have agreed in principle to adopt a system of passes which will use smart cards for cross-border travel (Phuket Gazette, 6 September 2004).

The implementation of ID cards has raised resistance and objections in various countries. The British Home Affairs Select Committee's report on smart ID card has expressed concerns over the ID card scheme (HC130-1, 2004). Some have expressed concerns over the potential impacts of ID cards on liberties, personal privacy and of its becoming a 'technological disaster', and suggested that the decisions on the scheme should be subject to parliamentary scrutiny (BBC News, 30 July 2004, http://news.bbc.uk/1/hi/uk_politics/3937535. $\mathrm{stm})$. Therefore, the potential impacts of smart ID cards on Thailand could be far reaching both for the country as a whole, in terms of financial burden, democratisation, political stability and national security, and 
for the people, in terms of freedom, liberty, privacy rights and human development. This paper will outline some background information on the smart ID card project in Thailand, public reactions and objections to the project, and an analysis of the smart card project from a Buddhist perspective to investigate the acceptability of the project from a Buddhist point of view. Relevant suggestions for public policy modifications will also be discussed.

\section{Smart ID Card in Thailand}

On 14 October 2003 the Cabinet asked the Ministry of Information and Communication Technology (MICT) to be in charge of the procurement and management of multipurpose identity cards or smart cards, including the cooperation among other government bodies concerning smart cards. In December 2003, the MICT requested Bt 1.82 billion for the smart card project, which included Bt 33.2 million for 33,198 card reader-writer machines for six agencies, $\mathrm{Bt}$ 132.79 million for 33,198 fingerprint reading machines and $\mathrm{Bt} 126$ million to laminate the cards (The Nation, 12 December 2003).

Subsequently, in January 2004 the Cabinet approved a 3-year smart card project starting in April 2004 and ending in the fiscal year 2007. The objectives of the project are to improve public service, increase efficiency, and reduce wasteful public investment by using one smart card to access all public services and to facilitate electronic transactions. The scheme is divided into three phases. The first phase aims at producing 12 million smart cards with a budget of $\mathrm{Bt} 1,670$ million for the fiscal year 2004. The second phase, with a budget of $\mathrm{Bt} 3.120$ billion for the 2005 fiscal year, will produce 26 million cards. The third phase has a budget of $\mathrm{Bt} 3.120$ billion for the remaining 26 million smart cards. (http:// www. thaipro. com/ news_00/ 201_Thai-smart-cards.html)

The information on the smart card will come from at least six different data sources, i.e. the Interior Ministry's population registration bureau, the social security department, the health and welfare database, the driving license bureau, the civil servant database and the database on farmers. Therefore, the information will include the card holder's name, address(es), date of birth, religion, nationality, blood type, allergies and chronic medical conditions, biometric images (fingerprints, face and iris), parents' names, marital status, social security details, health insurance, driving license details, taxation data, the Bt 30 healthcare scheme, and details of those officially registered as poor. (http://www.boingboing.net/2002/11/25/T hailand)

The first batch of 10,000 smart ID cards were handed out during a promotional campaign on Civil Servants Day to ordinary citizens, politicians, senior bureaucrats, media professional and celebrities (The Nation, 2 April 2004). The special target groups of card holders are those in the three provinces in the South where unrest and insurgency continue to occur. The collaboration with the Malaysian Government on cross-border passes by using smart cards is perceived to be a measure against insurgents escaping across the border. The other target groups are those people in the so-called IT Cities of Phuket, Chiang Mai and Khonkaen, and those officially registered as poor people. Moreover, the Ministry of Interior plans to issue smart cards for newborn babies and reduce the categories of people who are exempted from carrying ID cards from 28 to 7 categories (The Nation, 8 May 2004). 
On 29 June 2004, a consortium of ST Microelectronics, In Card Consortium and Cisco Engineering won a bid to produce 12 million smart cards for the MICT at a price of $\mathrm{Bt} 74$ per card, which amounts to $\mathrm{Bt} 888$ million, with a capacity of $66 \mathrm{~KB}$ per card (The Nation, 30 June 2004). In March 2005, the Cabinet approved an amendment of the draft bill on the national identity card to require parents of newborn babies to apply for ID cards within sixty days (Bangkok Post, 13 March 2005). Additionally, all children under 15 years old would be required to apply for ID cards within a year, while people over 70 years old can continue to use the old ID card. The period of validity of the ID cards is ten years, each costing 200 baht, more than from the 10 baht for the old ID card.

\section{Criticism against Smart ID Card}

An analyst from Gartner commented that the smart ID card project lacked adequate planning and proper consultation with experts in the private, public and industry sectors. The biggest problem of the project is seen to be the structure of the government funding in which each public body has its own budget and initiatives (CNET News.Com, 16 October 2003). Furthermore, legal experts have pointed out that the drafting of Data Protection legislation would take at least one more year (The Nation, 20 November 2003). They also argue that blood group details should not be stored in smart cards in case hospital staff input the data incorrectly. Currently there is no law to protect people from the misuse of personal data by government officials. The drafted legislation focuses only on data possessors and ignores the issues of data controllers and processors, most of whom are officials responsible for inputting personal data.
Concerns in the private sector over the lack of legislative protection have been voiced in a seminar organised by the CIO Forum Magazine. Legislation concerning electronic transactions should be enforced before the implementation of the smart card project and a pilot project should be thoroughly conducted (The Nation, 3 May 2004). In this way the public would become aware of the potential benefits of smart ID cards, while glitches found in the pilot project could be fixed in time. Medical experts also warn of the possibility of abuses of stored health information on smart cards. A member of the National Biometrics Committee said that smart cards could contain genetic information on top of blood group, allergies and chronic diseases, all of which could be useful to insurance companies (The Nation, 10 March 2004).

Civil rights groups say that smart ID cards could easily violate personal privacy and deprive one of one's liberties. They are especially worried about corrupt or unauthorised government officials who could use personal data to manipulate and control people (The Nation, 18 April 2004). The failure to maintain the accuracy and currency of the information could have adverse impacts on people's lives. The lack of data protection also leads to the distrust of government officials who could snoop and tamper with personal data, such as the case of the unlawful investigation of bank accounts belonging to newspaper editors and several public figures. During a seminar on 'Smart Card and Society', a member of the National Human Rights Commission again urged the government to enact a Data Privacy Act before implementing the smart card policy (The Nation, 12 November 2004). 


\section{Smart ID Card from a Buddhist perspective}

As the smart ID card project is one of the most urgent government policies to reform public services and expected to contribute to the government's effort against the southern insurgency and become a part of the Prime Minister's Operation Center (PMOC), the Buddha's teaching on good government seems to be the appropriate starting point for a discussion. The Dhammapadatthakatha records that the Buddha has pointed out that for a country to be happy it must have a just government which could be realised by the Buddha's 'Ten Duties of Kingship' (dasa-rajadhamma), as given by in the Jataka text (Rahula 1978). For modern times, the term 'king' or raja can be read as members of the Cabinet, government ministers, administrators and high ranking officials who are involved in and responsible for the tasks of governing and administrating the country.

The first duty is dana or charity, i.e. the ruler should not be attached to or crave wealth but rather he should distribute it to increase the welfare of the people. The second duty is sila or a high moral character, that he should observe at least the Five Precepts: abstain from harming life, cheating, stealing and exploiting others, committing adultery, uttering falsehood, and taking intoxicants drink. The third duty is pariccaga or sacrifice for the good of the people. The ruler must be prepared to give up all personal comfort and even his life for the people's welfare. The fourth is ajjava, $\mathrm{He}$ must be unbiased in discharging his duties and be sincere in his intention without deceiving the public. The fifth is maddava or kindness and integrity. $\mathrm{He}$ must have a genial temperament. The sixth is tapa or austerity in habits. He must have a simple lifestyle, not indulging in luxury. The seventh is akkodha or freedom from hatred and ill-will. He should bear no grudges against anybody. The eighth is avihimsa or non-violence. The ruler should try to promote peace and prevent war, including violence and the destruction of life. The ninth is khanti or patience, tolerance and understanding, He must be able to bear hardship, difficulties and insults without losing his temper. The tenth is avirodha or non-opposition, nonobstruction. The ruler should neither oppose the will of the people nor obstruct any relevant measures conducive to the welfare of the people, i.e. he should rule in harmony with his people.

According to the tenth duty of nonopposition, non-obstruction of the will and welfare of the people, the smart card project can be considered as failing to conform to Buddhist teaching. Despite opposition by various industry and legal experts and by academics and civil rights groups against the implementation prior to safeguarding people's privacy rights and liberties through relevant legislation, the government proceeded to approve funding for the production and distribution of smart cards. The potential damage from identity fraud, abusive and unauthorised usage of people's information, including encroachment on human rights, would not be conducive to the democratic process, economic stability, or the security of the country. There would be no harmony between the ruler or government and the people in the three southern provinces, where the information on smart cards could be used for discriminatory and abusive purposes which are not in accordance with the acceptable standards of good governance and human rights. Unless there are appropriate legal protection, and transparent and accountable procedures in 
using highly personal and sensitive information, mutual distrust and agitation would increase, to the detriment of the effort in countering insurgency. Moreover, ordinary citizens would feel insecure and be embraced by a climate of fear of surveillance by abusive government agents and their cronies, resulting in the constriction of liberties.

The smart card project also fails to conform to the fourth duty of good government, that is honesty and sincerity of intentions in discharging the government's duties. The earlier objectives of the smart card project aimed at improving public services by waste pruning, increasing efficiency and reducing fraud in the social security and welfare system. However, the wave of 'war on terrorism' from the west means that a hidden agenda has been added without consultation with stakeholders and experts. The initial implementation of smart cards in the three provinces in the South for the purpose of identifying potential suspects of insurgency is wishful thinking. The conception and design of the information system are based on flaws and are begging for critical systemic questions. The government needs to be seen as transparent and honest in its intentions and actions so as to reflect the worthiness of a good government.

The other duty of a good ruler or government which can be easily broken is the ninth duty of patience, forbearance, tolerance and understanding. The officials' disregard for the opposition towards smart cards reflects their lack of understanding of sincere concern of the people, by the people, for the welfare of the country as a whole. Private sector experts have pointed out the potential for systems failure and a wasteful budget, while others have pointed out potential adverse social impacts. The government has not shown due patience and tolerance towards criticism, For example, many media and news reporters have become self-censored in their reporting of issues which concern the well being and security of all the people in the country.

Therefore, according to Buddhism's 'Ten Duties of Kingship', the smart card project has left much to be desired in order to come up to an acceptable level of being in accord with the Buddhist spirit. The other Buddhist teaching which could be applied to the discussion is the Noble Eightfold Path or the Middle Path which consists of right understanding, right intention, right speech, right action, right livelihood, right effort, right mindfulness and right concentration (Rahula 1978). Fortunately, the smart ID card project conforms to some of the Noble Eightfold Path. Some of the intentions of the project are worthy of praise, i.e. the intention to improve access to public services, their quality and efficiency. However, lack of understanding, that some humanitarian or welfare objectives are inherently in conflict with law-and-order and security objectives, leads to disharmony between the government and the people. This makes it very difficult, if not impossible, for policy implementation to involve right effort, right action, right mindfulness and right concentration. The objective of countering terrorism deserves a special information systems project, which requires an entirely different category of actions, efforts and concentration.

Furthermore, the smart card project will exacerbate the social, economic and digital divides in society. According to the Buddhist view on sustainable development, the success of various social systems depends on inter-relationships among 
various systems and their sub-systems (Phra Dhammapitaka 1995). The emphasis should be on having diversified measures which would create an atmosphere of nondamaging or non-exploitation, an atmosphere of kind assistance. Government should offer protection for disadvantaged and less fortunate people and should prevent stronger members from exploiting the weak so as to enable all people the opportunities for self-development. The smart ID cards will put marginalised and minority groups, such as hill tribe people, immigrant workers, illegal foreign workers, homeless people and refugees, including illiterate citizens, at the other end of the social spectrum, making it harder for them to access public services, and creating more difficulties in proving their entitlements and identities.

These smart ID cards and corresponding legal requirements would impose further legal and financial burdens on the poor and disadvantaged. The requirements for newborn babies to have ID cards at 200 baht a piece means that a family of triplets will have to bear the 600 baht cost for three ID cards every 10 years for cardrenewal, each time the information on the cards in need of updating. The financial burden would be specially felt among large families in the poor agricultural sector, as all children under 15 years old are also obliged to acquire smart ID cards. Extra costs will be incurred whenever the cards are damaged, lost or stolen, or required to be updated or changed and renewed every ten years. This does not include the social, economic, humansecurity and opportunity costs of the smart ID card scheme, which could be far higher than the government anticipates, as there have been no reports on feasibility studies or cost-benefit analysis of the scheme to date. The unintended consequences would likely be increased the problems of identity fraud, human trafficking, economic crime and difficulties in uncovering insurgency. A more strenuous application of the understanding principle of the Middle Path and a more charitable attitude of the government would create more harmony and well-being for the people by redressing their plights and burdens.

The impending development of e-service and e-citizen via smart cards means that those who do not have computer skills, cannot access the Internet, or do not have computers will be left on the far side of the digital divide. The interdependent relationships of these social systems would be damaged to the detriment of the wellbeing of society as a whole, creating more poverty, social inequality, enlarging the various divides, accumulating problems and obstacles to sustainable development.

Hence, the smart card project has not fulfilled the Buddhist ideal of developing human beings so as to be 'above' technology in order to protect and ensure freedom and liberty which are requisites for the pursuit of knowledge and enlightenment (Phra Dhammapitaka 1997). The project also confirms Phra Dhammapitaka's observation about modern Thai culture in its exhibiting indulgence in consuming modern technology and its dependency on the gratification of technology consumption.

\section{Lessons from the British ID Card scheme}

By harvesting useful lessons from the British experience with their ID card scheme, a deeper understanding of the complexity of the scheme can become the basis for policy adjustments and recommendations. Firstly, the British 
scheme occurred in a highly democratic culture and open government in which legislative mechanisms guarantee the existence of a proper consultation process, including good practice rules and guidelines for good governance. For example, the UK Home Office conducted a consultation exercise on the ID card by following the seven criteria set out in the Cabinet Office Code of Practice on written consultations. Some of the criteria include the inclusion of consultation in the policy planning process, targeted groups and questions for consultation, circulation of documents with the fullest use of electronic means, a minimum period of 12 weeks for consultation, the publication of the results, and the coordination and dissemination of lessons from the exercise (CM 6019 2003).

The important themes of the general public views against the ID card in the UK consist of human rights issues, whereby many people believe that they have the right to live an anonymous life. Secondly, the ID card scheme is unacceptable on the grounds of cost, both in terms of what a person must pay for his card and the burden on taxpayers in setting up and running the whole system. Thirdly, the British government's long history of failure in handling large-scale computer projects makes people very concerned about the ability to run a large ID card scheme. Fourthly, people fear that there would not be adequate protection against the abuse and misuse of personal data. Fifthly, there is the fear of 'function creep', whereby the government will use the data for other purposes. The other important opposition lies at the backbone of the scheme, i.e. the issue of biometrics with regards to civil rights and privacy, and the questions about the reliability of recent and untested biometrics technology.

\section{Some suggestions from a Buddhist perspective}

By adopting some of the 'Ten Duties of Kingship', the Thai government and their responsible officials could start a review of the smart ID card policy. Not only would this action be beneficial to the improvement of the scheme but also lead to a better atmosphere for fostering democratic development and the well-being of all social systems. To adhere to the duty of ajjava (honesty and sincerity), government officials should make public the objectives and details of the scheme so that open consultation and public scrutiny could the findings widely published be conducted in a meaningful way. Perhaps some of the UK code of good practice can be adopted for the consultation process and publish the findings widely. Secondly, the duties of maddava (kindness), (italics) (freedom from ill-will), khanti (patience, tolerance, understanding), and avirodha (nonobstruction) should lead to other protective measures such as legislation, procedure and rules, (e.g. Data Protection Act, Privacy Law) and a relevant electronic transaction law, that could be urgently enacted and implemented before using smart cards.

Thirdly, pariccaga (sacrifice for people's welfare) and avihimsa (non-violence, promoting peace) would apply to the budget and time allowance for a few pilot projects to ensure that different target groups of people could be involved in the consultation exercise and testing process. Fourthly, the first duty of dana (charity) would urge the government to implement appropriate measures for redressing the problems of the digital divide vis-à-vis the smart card scheme among those in remote areas, the less educated and less computer savvy, minorities and vulnerable people, and the socially and economically 
disadvantaged. Finally, regarding the duty of 'being unbiased in discharging his duty', the government should commission an independent investigation on Statutory Impact Assessment, including a study of the potential socio-economic impacts of the proposed policy. These reports should be made public and circulated as widely as possible so that people become aware of the impacts of smart cards.

The results of the application of these suggestions could be formidable and unexpected in terms of learning experiences and growing pains in the democratisation process. Whether the government encounters major changes or modifications or even failure, the government that adheres to the 'Ten Duties of Kingship' will always be accepted and sympathised with as people will perceive their honesty and wellintended effort. The Buddha said: 'Never by hatred is hatred appeased, but it is appeased by kindness. One should overcome anger through kindness, wickedness through goodness, selfishness through charity, and falsehood through truthfulness.' (Rahula 1978, 86)

\section{References}

Bangkok Post. 13 March 2005. Perspective Sunday. Bangkok.

BBC News. 2004. ID Cards Plans 'badly thought out'. London. http://www.bbc.co.uk/1/hi/uk_politi cs/3937535.stm (30 July 2004).

Brown, I. 2004. ID Card Scheme an expensive flop. London: FIPR.

Bunyan, T. 2002. Statewatch Analysis no.13: the war on freedom and democracy. London. http://www.statewatch.org/news
The Canberra Times. 2001. Malaysia's smart card touted as weapon against terrorism. Canberra, Australia. (21 September 2001).

CM 6019. 2003. Identity Cards: a summary of findings from the consultation exercise on entitlement cards and identity fraud. Norwich: HMSO.

CNET News.com. 16 October 2003.

HC 130-1. 2004. Identity Cards. Home Affairs Committee Fourth Report. London: Stationary Office.

Phra Dhammapitaka. 1995. Sustainable Development. Bangkok: KomolKeamtong Foundation.

Phra Dhammapitaka. 1997. Life in Technological Society. Bangkok: Buddha-Dhamma Foundation.

Phuket Gazette. 16 August 2004. Phuket: Thailand.

Rahula, W. 1978. What the Buddha Taught. London: Gordon Fraser.

The Nation. 11 November 2002. Egovernment needs a data-protection law. Bangkok.

The Nation. 20 November 2003. Bangkok.

The Nation. 12 December 2003. Bangkok.

The Nation. 10 March 2004. Bangkok.

The Nation. 2 April 2004. Bangkok.

The Nation. 18 April 2004. Editorial Smart cards Must Come with Laws. Bangkok. 
The Nation. 3 May 2004. Bangkok.

The Nation. 8 May 2004. Bangkok.

The Nation. 12 November 2004. Bangkok.

The Nation. 30 June 2004. Bangkok.

\section{Websites}

http://www.privacy.org/pi/activities/idcard

http://www.thaipro.com/news 00/201 Th

ai-smart-cards.html

http://www.boingboing.net/2002/11/25/Th ailand

http://www.bbc.co.uk/1/hi/uk politics/393 $\underline{7535 . \mathrm{stm}}$

http://www.statewatch.org/news 